\title{
Current Progress in Solution Precursor Plasma Spraying of Cermets: A Review
}

\author{
Romnick Unabia ${ }^{1,2, *}$, Rolando Candidato Jr. ${ }^{1}$ and Lech Pawłowski ${ }^{2}$ \\ 1 Physics Department, College of Science and Mathematics, MSU-Iligan Institute of Technology, \\ Iligan City 9200, Philippines; r.candidatojr@gmail.com \\ 2 IRCER UMR 7315 CNRS, University of Limoges, Limoges Cedex 87068, France; lech.pawlowski@unilim.fr \\ * Correspondence: romnickunabia@gmail.com; Tel.: +33-0-587-502-400
}

Received: 1 May 2018; Accepted: 1 June 2018; Published: 4 June 2018

\begin{abstract}
Ceramic and metal composites, known also as cermets, may considerably improve many material properties with regards to that of initial components. Hence, cermets are frequently applied in many technological fields. Among many processes which can be employed for cermet manufacturing, thermal spraying is one of the most frequently used. Conventional plasma spraying of powders is a popular and cost-effective manufacturing process. One of its most recent innovations, called solution precursor plasma spraying (SPPS), is an emerging coating deposition method which uses homogeneously mixed solution precursors as a feedstock. The technique enables a single-step deposition avoiding the powder preparation procedures. The nanostructured coatings developed by SPPS increasingly find a place in the field of surface engineering. The present review shows the recent progress in the fabrication of cermets using SPPS. The influence of starting solution precursors, such as their chemistry, concentration, and solvents used, to the micro-structural characteristics of cermet coatings is discussed. The effect of the operational plasma spray process parameters such as solution injection mode to the deposition process and coatings' microstructure is also presented. Moreover, the advantages of the SPPS process and its drawbacks compared to the conventional powder plasma spraying process are discussed. Finally, some applications of SPPS cermet coatings are presented to understand the potential of the process.
\end{abstract}

Keywords: cermets; cermet applications; solution precursor plasma spraying; microstructure

\section{Introduction}

Recent studies demonstrate that deposition of coatings composed of metal phase embedded in ceramic matrix have considerably improved properties, such as hardness, wear resistance, surface reactivity, etc. [1-10]. The composite system of ceramics and metallic phases are known as cermets.

Atmospheric plasma spraying (APS) is a conventional thermal spray process which has been widely, and for many years, used for deposition of cermets used as protective coatings [1,3], thermal barrier coatings [4-6], and coatings in solid oxide fuel cells (SOFC) [7-9]. On the other hand, the production of coatings with fine microstructures (sub-micrometer/nanometer-scale) has been developed since the mid-1990s. These coatings improved its physical and mechanical properties, such as surface area, solubility, and many others [11-20]. One of the limitations of the APS process is the use of micrometer-sized $(10-100 \mu \mathrm{m})$ powder feedstocks which makes it difficult to produce fine coating microstructures [17-20]. In addition, the resulting APS coatings have a characteristic lamellar structure due to successive impingement of splats, which reveals micro-defects such as unmelted particles, gas pores, and weak interconnection between splats that could deteriorate the coating's functionality $[4,5]$. Therefore, the use of liquid feedstock in thermal spraying, such as the solution 
precursor plasma spraying process (SPPS), has been developed to overcome the limitations of the APS process [21,22].

SPPS offers a single-step deposition process of finely-structured cermet coatings by employing molecularly-mixed liquid precursors directly as the feedstock, which enables avoiding the powder and suspension preparation as shown in Figure 1 [10,13,14,17-19]. The use of solution precursors for thermal spraying was initiated by Karthikeyan et al. [21]. SPPS coating technology is industrially advantageous due to its ease in feedstock preparation.
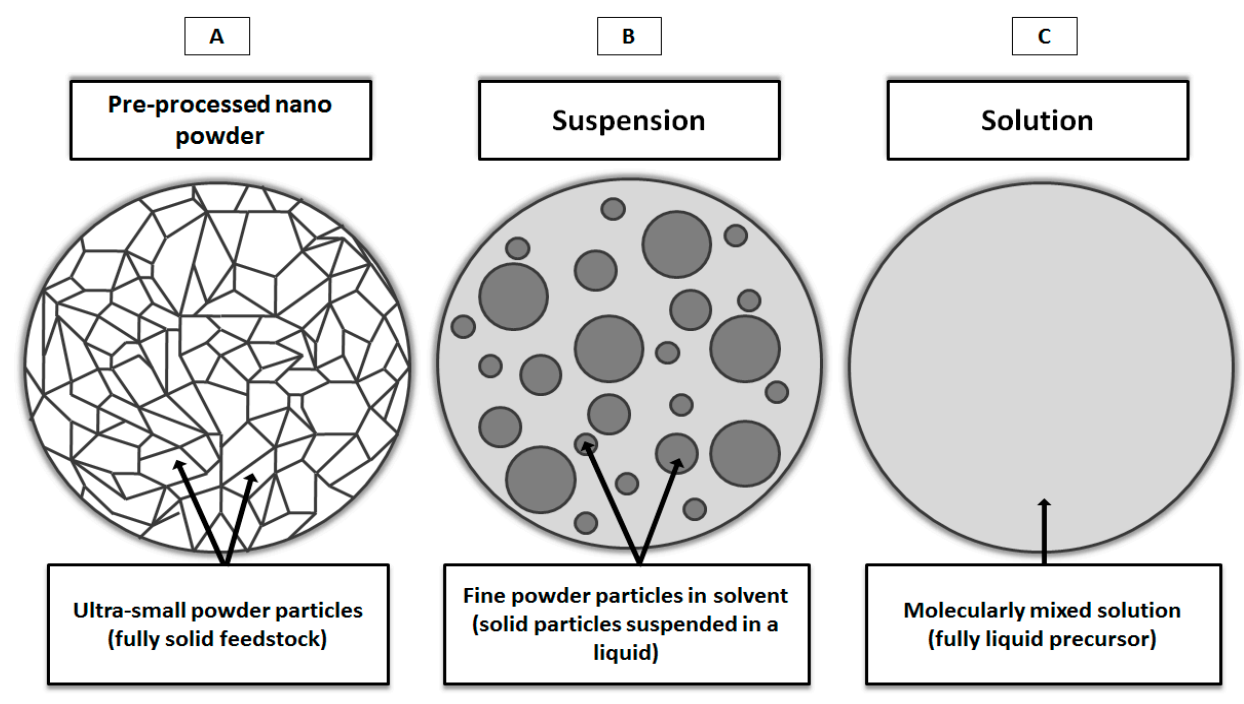

Figure 1. Feedstocks used for thermal spraying processes which enable to obtain nano-structured coatings: (A) the pre-processed nano-powder particle used for the APS process; (B) the suspension droplet used for the SPS process; and $(\mathbf{C})$ the homogeneously-mixed solution droplet used for SPPS process.

Since the beginning of 21st century, there has been rapid development in nanostructured coating deposition using the SPPS process as reflected by a number of published articles [15-22]. However, most of the accounted papers focus on the deposition of ceramic materials alone and only a few have been reported on SPPS coating deposition for cermets (ceramic-metal composite) because of the oxidation potential of the metal-ions in the solution precursor $[10,15]$. The present review focuses on the current progress of solution precursor plasma spray for depositing cermet coatings used in various applications. In particular, the review gives an overview of the various factors affecting the final coating material, such as solution precursor preparations and physico-chemical interaction of the solution precursor with the high-temperature plasma jet.

\section{Solution Precursor Plasma Spraying of Cermets}

The properties of the starting solution precursors and operational plasma spray process parameters greatly influenced the physical and chemical characteristics of sprayed coatings. Thus, it is very important to screen those parameters which influence most of the properties of cermet coatings. Some of them are presented in Figure 2 together with the schematic representation of SPPS process. Selected parameters are discussed in the subsequent sections. 


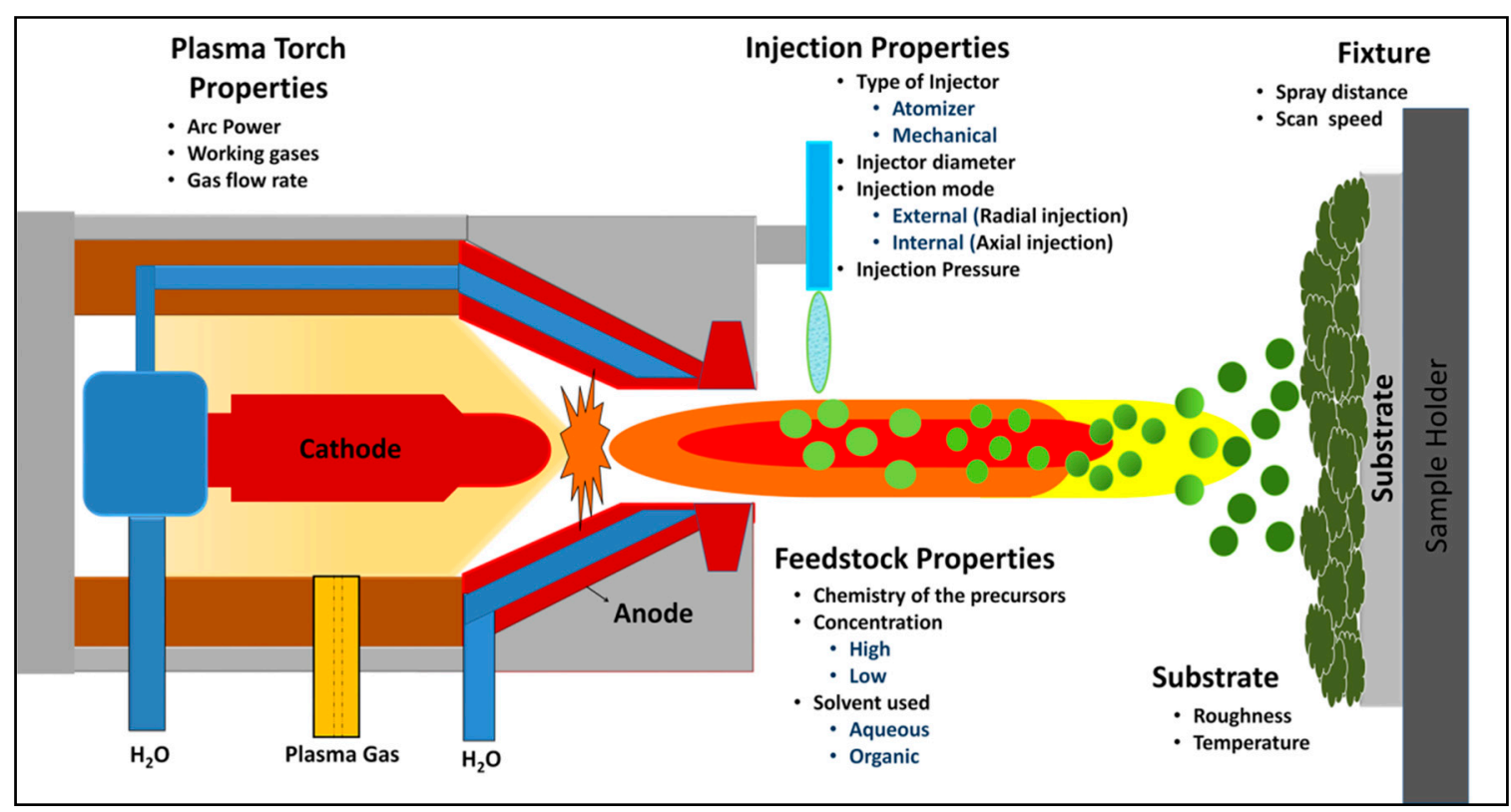

Figure 2. Schematic diagram of the solution precursor plasma spraying process showing the many different and important operational spray parameters that could influence the physical and chemical characteristics of cermet coatings.

\subsection{Solution Precursor Preparation}

Solution precursors are generally prepared by mixing salts of metals such as nitrates and acetates in desired stoichiometry using various solvents (see Table 1). The chemistry of solution precursors, their concentration and solvent used, determine the characteristics of the resulting coatings [10,22-29]. The spraying process is accompanied by the decomposition of the precursor at the elevated temperature and high heat transfer of the plasma jet $[10,22-25]$.

Table 1. Solution precursor preparation for cermet coating fabrication via SPPS.

\begin{tabular}{|c|c|c|c|c|c|}
\hline Final Coating & $\begin{array}{l}\text { Coating } \\
\text { Application }\end{array}$ & Precursor & Solvent Used & Additive & Reference \\
\hline Zinc ferrite, $\mathrm{ZnFe}_{2} \mathrm{O}_{4}$ & Photocatalysis & $\begin{array}{c}\text { Zinc nitrate }\left[\mathrm{Zn}\left(\mathrm{NO}_{3}\right)_{2} \cdot 6 \mathrm{H}_{2} \mathrm{O}\right] \\
\text { and ferric nitrate } \\
{\left[\mathrm{Fe}\left(\mathrm{NO}_{3}\right)_{3} \cdot 9 \mathrm{H}_{2} \mathrm{O}\right] ; \text { ratio }} \\
{[\mathrm{Zn} / \mathrm{Fe}=1 / 2]}\end{array}$ & $\begin{array}{l}\text { De-ionized } \\
\text { water } \\
\text { Ethylene glycol }\end{array}$ & $\begin{array}{l}350 \mathrm{mM} \text { citric } \\
\text { acid }\end{array}$ & $\begin{array}{l}\text { Dom, R. et al. } \\
{[10]}\end{array}$ \\
\hline $\mathrm{SrZrO}_{3}$ & Thermal barrier & $\begin{array}{c}\text { Zirconium acetate } \\
{\left[\mathrm{Zr}\left(\mathrm{C}_{2} \mathrm{H}_{4} \mathrm{O}_{2}\right)_{4}\right] \text { and strontium }} \\
\text { nitrate tetrahydrate } \\
{\left[\mathrm{Sr}\left(\mathrm{NO}_{3}\right)_{2} \cdot 4 \mathrm{H}_{2} \mathrm{O}\right] ;} \\
\text { concentration }=1.6 \mathrm{~mol} / \mathrm{L}\end{array}$ & $\begin{array}{l}\text { De-ionized } \\
\text { water }\end{array}$ & - & Li, X. et al. [12] \\
\hline $\begin{array}{c}\text { Zinc-hydroxyapatite, } \\
\text { Zn-HA }\end{array}$ & Biomedical & $\begin{array}{c}\text { Zinc nitrate hexahydrate } \\
{\left[\mathrm{Zn}\left(\mathrm{NO}_{3}\right)_{2} \cdot 6 \mathrm{H}_{2} \mathrm{O}\right], \text { calcium }} \\
\text { nitrate tetrahydrate } \\
{\left[\mathrm{Ca}\left(\mathrm{NO}_{3}\right)_{2} \cdot 4 \mathrm{H}_{2} \mathrm{O}\right], \text { and }} \\
\text { tri-ethyl phosphite }\left[\mathrm{P}(\mathrm{OEt})_{3}\right] \\
\text { ratio }[(\mathrm{Ca}+\mathrm{Zn}) / \mathrm{P}=1.67]\end{array}$ & $\begin{array}{l}\text { De-ionized } \\
\text { water }\end{array}$ & - & $\begin{array}{l}\text { Candidato, R. } \\
\text { et al. [13] }\end{array}$ \\
\hline $\begin{array}{l}\text { Cobalt ferrite, } \\
\mathrm{CoFe}_{2} \mathrm{O}_{4}\end{array}$ & $\begin{array}{c}\text { Biomedical, } \\
\text { biomagnetic, } \\
\text { and } \\
\text { Antibacterial }\end{array}$ & $\begin{array}{c}\text { Cobalt nitrate } \\
{\left[\mathrm{Co} .\left(\mathrm{NO}_{3}\right)_{2} \cdot 6 \mathrm{H}_{2} \mathrm{O}\right] \text { and ferric }} \\
\text { nitrate }\left[\mathrm{Fe}\left(\mathrm{NO}_{3}\right)_{3} \cdot 9 \mathrm{H}_{2} \mathrm{O}\right] ; \text { ratio } \\
{[\mathrm{Co} . / \mathrm{Fe}=1 / 2]}\end{array}$ & $\begin{array}{l}\text { De-ionized } \\
\text { water }\end{array}$ & $\begin{array}{l}\text { Citric acid as } \\
\text { chelating agent }\end{array}$ & $\begin{array}{c}\text { Sanpo et al. } \\
\text { [14]; } \\
\text { and Sanpo et al. } \\
{[15]}\end{array}$ \\
\hline $\begin{array}{l}\text { Nickel- Yttria } \\
\text { stabilized zirconia, } \\
\text { Ni-YSZ }\end{array}$ & $\begin{array}{l}\text { Solid oxide fuel } \\
\text { cell (SOFC) }\end{array}$ & $\begin{array}{c}\mathrm{ZrOCl}_{2} \cdot 6 \mathrm{H}_{2} \mathrm{O}, \mathrm{Y}\left(\mathrm{NO}_{3}\right)_{3} \cdot 6 \mathrm{H}_{2} \mathrm{O} \\
\text { and } \mathrm{Ni}\left(\mathrm{NO}_{3}\right)_{3} \cdot 6 \mathrm{H}_{2} \mathrm{O} ; \\
\text { concentration } 60 \text { vol. \% of } \\
8 \% \mathrm{YSZ} \text { and } 40 \text { vol. } \% \text { of } \mathrm{Ni}\end{array}$ & Distilled water & - & $\begin{array}{l}\text { Wang, Y, and } \\
\text { Coyle, T.W. [23] }\end{array}$ \\
\hline
\end{tabular}


Table 1. Cont.

\begin{tabular}{|c|c|c|c|c|c|}
\hline Final Coating & $\begin{array}{c}\text { Coating } \\
\text { Application }\end{array}$ & Precursor & Solvent Used & Additive & Reference \\
\hline $\begin{array}{l}\text { Strontium doped } \\
\quad \text { lanthanum } \\
\text { manganite, } \\
\mathrm{La}_{0.8} \mathrm{Sr}_{0.2} \mathrm{MnO}_{3}, \mathrm{LSM}\end{array}$ & $\begin{array}{l}\text { Solid oxide fuel } \\
\text { cell (SOFC) }\end{array}$ & $\begin{array}{c}\mathrm{La}\left(\mathrm{NO}_{3}\right)_{3} \cdot 6 \mathrm{H}_{2} \mathrm{O}, \mathrm{Sr}\left(\mathrm{NO}_{3}\right)_{2} \\
\text { and } \mathrm{Mn}\left(\mathrm{NO}_{3}\right)_{2} ; \text { molar ratio } \\
\text { La:Sr:Mn = 0.8:0.2:1; total } \\
\text { concentration } 0.1 \mathrm{~mol} / \mathrm{L}\end{array}$ & $\begin{array}{l}\text { Distilled water } \\
\text { Ethanol }\end{array}$ & - & $\begin{array}{l}\text { Wang, X. et al. } \\
\text { [24] } \\
\text { Wang, X. et al. } \\
\text { [29] }\end{array}$ \\
\hline $\begin{array}{l}\text { Strontium doped } \\
\text { samarium cobaltite, } \\
\mathrm{Sm}_{0.7} \mathrm{Sr}_{0.3} \mathrm{Co}_{3-\delta}\end{array}$ & $\begin{array}{l}\text { Solid oxide fuel } \\
\text { cell (SOFC) }\end{array}$ & $\begin{array}{l}\mathrm{Sm}\left(\mathrm{NO}_{3}\right)_{3} \cdot 6 \mathrm{H}_{2} \mathrm{O}, \mathrm{Sr}\left(\mathrm{NO}_{3}\right)_{2} \\
\text { and } \mathrm{Co} .\left(\mathrm{NO}_{3}\right)_{3} \cdot 6 \mathrm{H}_{2} \mathrm{O} ; \text { molar } \\
\text { ratio Sm:Sr:Co. }=0.7: 0.3: 1 ; \\
\text { total concentration } 0.1 \mathrm{~mol} / \mathrm{L}\end{array}$ & $\begin{array}{l}\text { Ethanol and } \\
\text { distilled water }\end{array}$ & - & $\begin{array}{c}\text { Li, C.X. et al. } \\
{[25]}\end{array}$ \\
\hline
\end{tabular}

Lay et al. [26] reported the influence of the chemistry of the starting precursors on nickel-based SPPS cermet. They found that nickel-samaria doped ceria (Ni-SDC) has larger quantity of finer particles than nickel-yttria stabilized zirconia (Ni-YSZ) [26]. Moreover, Wang et al., [24] reported that the utilization of strontium-doped lanthanum manganite, $\left(\mathrm{La}_{0.8} \mathrm{Sr}_{0.2} \mathrm{MnO}_{3}\right)$ as $\mathrm{SOFC}$ cathode material shows promising characteristics i.e., high electrochemical activity and thermal stability due to its high operating temperature $\left(>800{ }^{\circ} \mathrm{C}\right.$ ) compared to $\mathrm{Sm}_{0.5} \mathrm{Sr}_{0.5} \mathrm{CoO}_{3}$ and $\mathrm{La}_{0.6} \mathrm{Sr}_{0.4} \mathrm{Co}_{0.2} \mathrm{Fe}_{0.8} \mathrm{O}_{3}$.

It was also reported that the good stoichiometric ratio of the ceramic-metallic species and/or the addition of complexing/chelating agent such as citric acid in the solution precursor can modify the chemistry of the solution [10,13-15]. Dom et al. [10] showed that the stoichiometric ratio of Zn to Fe being about 1:2 could thermodynamically favor the formation of desired cermet zinc ferrite composite phase rather than their corresponding metal-oxide phases such as zinc oxide, iron oxide, etc. [10]. Candidato et al. [13] also reported that as the zinc ion concentration into the hydroxyapatite (HA) ceramic matrix increases, formation of HA phases is hindered and favors the formation of calcium zinc phosphate impurity phase as shown in Figure 3. In addition, Sanpo et al. [15] presented that the utilization of citric acid as chelating agent with $20 \%$ concentration significantly favors the formation of more than $90 \%$ of cobalt ferrite phase due to chelate effect attributed to an increase in entropy resulting to a more stable composite material [15].

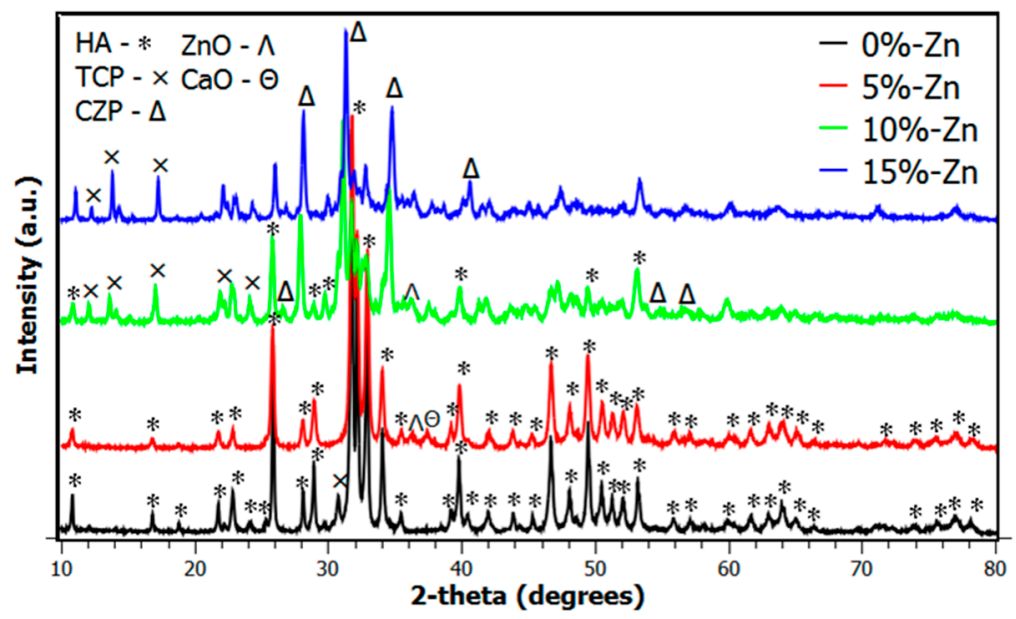

Figure 3. X-ray diffraction diagram of the Zn-doped HA cermet coatings showing the evolution of the calcium zinc phosphate phase as zinc ion concentration increases. Reproduced with permission from [13], Elsevier, 2018.

The concentration of the solution precursors is another aspect to be considered as it significantly influences the viscosity and surface tension of solution but has small effect on the pyrolysis and crystallization temperatures. High concentration solutions normally have higher viscosity and surface tension and need more injection pressure to be delivered to the core of the plasma jet. Solutions having low-concentration precursors generally experience surface precipitation leading 
to the formation of shells, while a highly-concentrated solution experiences volumetric precipitation leading to fully-melted splat microstructures. In order to induce volumetric precipitation, solution concentration must be near the equilibrium saturation concentration [17,27-30]. With these, high concentration solution precursors are used to deposit dense coatings. For example, Dom et al. [10] reported that a low concentration of zinc ferrite solutions yielded lower film thickness build-up per pass and certain impurity phases were observed, while high concentration yields a major fraction of zinc ferrite phases. However, beyond the equilibrium saturation concentration, the presence of unreacted solution precursor species was observed due to incomplete pyrolysis, thereby obtaining impurity phases in the coating.

The choice of solvent in the solution preparation is also important in the coating deposition as it relates to the ionic interactions at the molecular level due to macroscopic solvent properties, such as viscosity, surface tension, etc., and could modify the plasma jet's thermodynamic and transport properties which directly affect the splat formation (see Table 2) [10,24,28-30].

Table 2. Properties of two solvents commonly used in the SPPS process.

\begin{tabular}{|c|c|c|c|c|c|}
\hline Solvent & $\begin{array}{c}\text { Surface Tension } \sigma_{\mathrm{s}} \\
\left(\mathrm{J} \cdot \mathrm{m}^{-2}\right) \\
\text { (Room Temp.) }\end{array}$ & $\begin{array}{l}\text { Viscosity } \mu_{\mathrm{s}}(\mathrm{Pa} \cdot \mathrm{s}) \\
\text { (Room Temp.) }\end{array}$ & $\begin{array}{l}\text { Specific Heat } c_{\mathrm{p}} \\
\left(\mathrm{J} \cdot \mathrm{kg}^{-1} \cdot \mathrm{K}^{-1}\right) \text { (at } \\
\text { Room Temp.) }\end{array}$ & $\begin{array}{l}\text { Latent Heat of } \\
\text { Evaporation } L_{v} \\
\left(\mathrm{~J} \cdot \mathrm{kg}^{-1}\right)\end{array}$ & $\begin{array}{c}\text { Evaporation } \\
\text { Temperature } \\
T_{\mathrm{v}}(\mathrm{K})\end{array}$ \\
\hline Water & $72 \times 10^{-3}$ & $10^{-3}$ & $4.18 \times 10^{3}$ & $2.26 \times 10^{6}$ & 373 \\
\hline Ethanol & $22 \times 10^{-3}$ & $1.06 \times 10^{-3}$ & $2.44 \times 10^{3}$ & $0.84 \times 10^{6}$ & 351 \\
\hline
\end{tabular}

Aqueous solution precursor feedstock is prone to produce larger droplet size due to its high surface tension affecting the droplet breakup. This phenomenon leads to the production of partially-pyrolyzed splats. A work by Wang et al. [24] on LSM cermet coatings reported porous sponge-like deposits and layered microstructure when the aqueous solution is used. These microstructures were attributed to the incomplete evaporation of solvent in-flight producing partially-pyrolyzed splats and in situ pyrolysis further occurs on the substrate [24]. This phenomenon is observable in aqueous solution due to the cooling effect of water, resulting in a ca. $25 \%$ decrease of the zone of high temperature in the plasma jet at over $8000 \mathrm{~K}$ [30].

On the contrary, when ethanol was employed as solvent, LSM cermets had a porous morphology with a large number of agglomerated small particles $(0.2$ to $2 \mu \mathrm{m})$ [29]. Unlike the aqueous solution, microstructures with mostly-crystallized perovskite phases were observed in LSM coatings when using ethanol as the solvent [29]. In another work, the production of zinc ferrite coatings using organic solvent exhibited an impurity phase $\left(\mathrm{Fe}_{2} \mathrm{O}_{3}\right)$ unlike using aqueous solution, as shown in Figure 4 [10]. This can be attributed to easier evaporation of ethanol compared to water and to increase of plasma enthalpy and thermal conductivity, leading to a complete physical and chemical change of the precursor droplets, i.e., evaporation, precipitation, and densification inside the plasma jet region [24,28-30]. Chen et al. [28] investigated the phenomena related to the surface tension and evaporation. The authors reported that droplets having high surface tension and high boiling point solvent did not fully evaporate in the plasma while the solution droplets formed by the solvent having low surface tension and low boiling point could evaporate rapidly and could completely transform [28].

Lastly, appropriate solvents can be selected according to the application of the coatings, i.e., [27-30]:

- Aqueous solution precursor for the production of porous coatings (thermal barriers and biomedical ones);

- Organic solvent resulting in fully-melted splats and a dense coating architecture for anti-wear applications. 

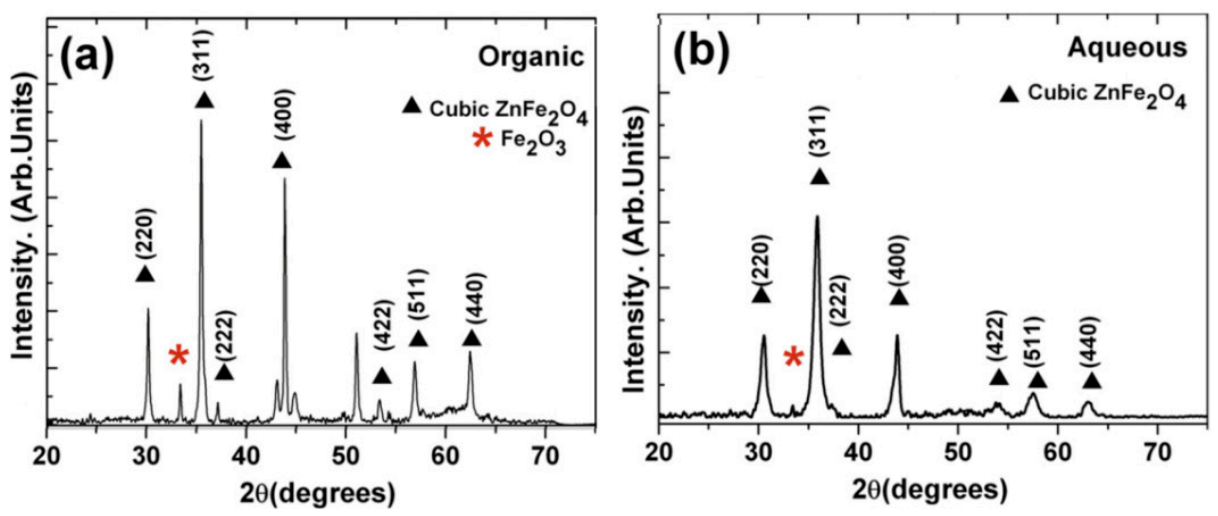

Figure 4. X-ray diffraction spectra of deposited zinc ferrite films using (a) ethylene glycol, and (b) water as precursor solvents. Reproduced with permission from [10], Elsevier, 2012.

\subsection{Injection of Solution Feedstock}

The mechanism of solution injection into the plasma jet affects the heating of the droplets. The solution inside a pressurized container can be fed using a pneumatic system or in an open container using a peristaltic pump. The flow rate can be easily adjusted by varying the pressure or rotation of the roller, respectively. In general, clogging is not a problem in SPPS, unlike in the APS process. However, a flexible pipeline must be used and flushing the injector with ethanol or water is recommended to avoid gelling of the solution inside the injector. The types of injection that are frequently used in SPPS can be categorized depending on the type of injector used (mechanical or atomizing injector), the mode of injection (internal or external) and, on the choice between radial and axial injection setup $[17,23,30,31]$. The solution inside a pressurized container can be fed using a pneumatic system or in an open container using a peristaltic pump, as shown in Figure 5.

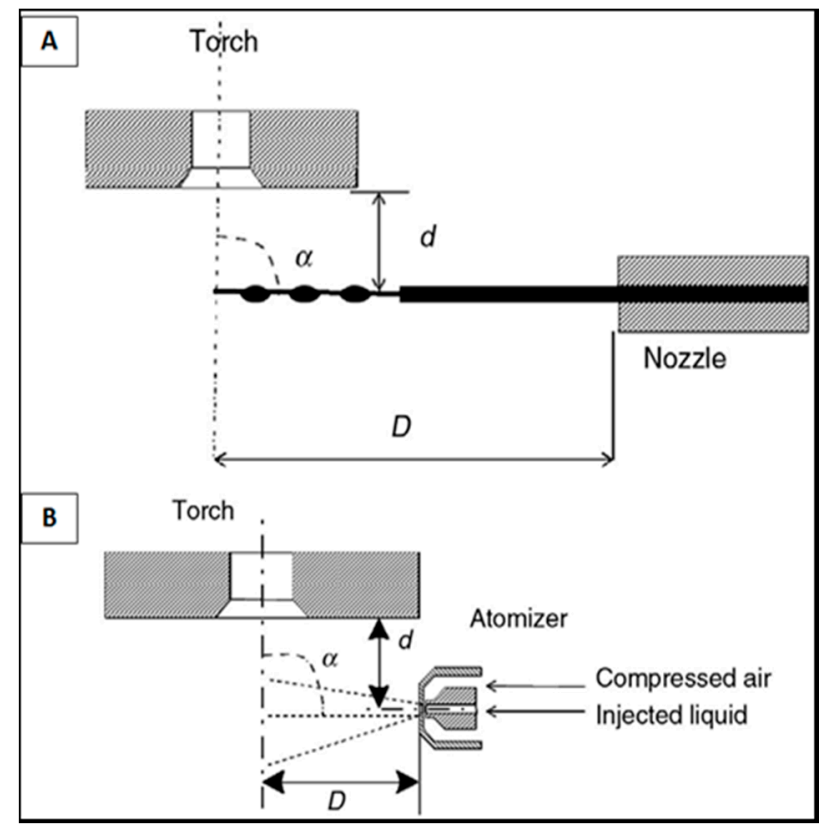

Figure 5. Schematic representation of the (A) mechanical injection and (B) spray atomization under external injection mode. Reproduced with permission from [17], Elsevier, 2009.

Mechanical injectors may use motor rollers to control the flow rate of the solution stream [22]. The formation of droplets from this stream is induced by an aerodynamic breakup through constant 
application of pressure, as shown in Figure 5A [17]. The resulting droplets using a mechanical injector are observed to have a relatively wide distribution of large droplets.

The large droplets may experience primary break-up before entering the plasma region. Upon penetrating at the plasma region, these large droplets undergo secondary break-up into smaller ones, as shown in Figure 6, influenced by the drag force acting on the droplet and its surface tension, which leads to the formation of finer microstructures [32]. With the high momentum of the large droplets, it can penetrate into the plasma core, enabling the droplet to be heated effectively. However, the good penetration of the stream of solution requires that the dynamic pressure of the solution is greater than the dynamic pressure of the plasma. This may be mathematically expressed as [17,22]:

$$
\rho v^{2} \text { solution }>\rho v^{2} \text { plasma, }
$$

Wang et al. [24], reported that mechanically-deposited strontium-doped lanthanum manganite (LSM) coatings present a partially crystallized perovskite phase with a fraction of the amorphous structure which could be attributed to the penetration and dwell time of the droplets in the plasma jet [24].

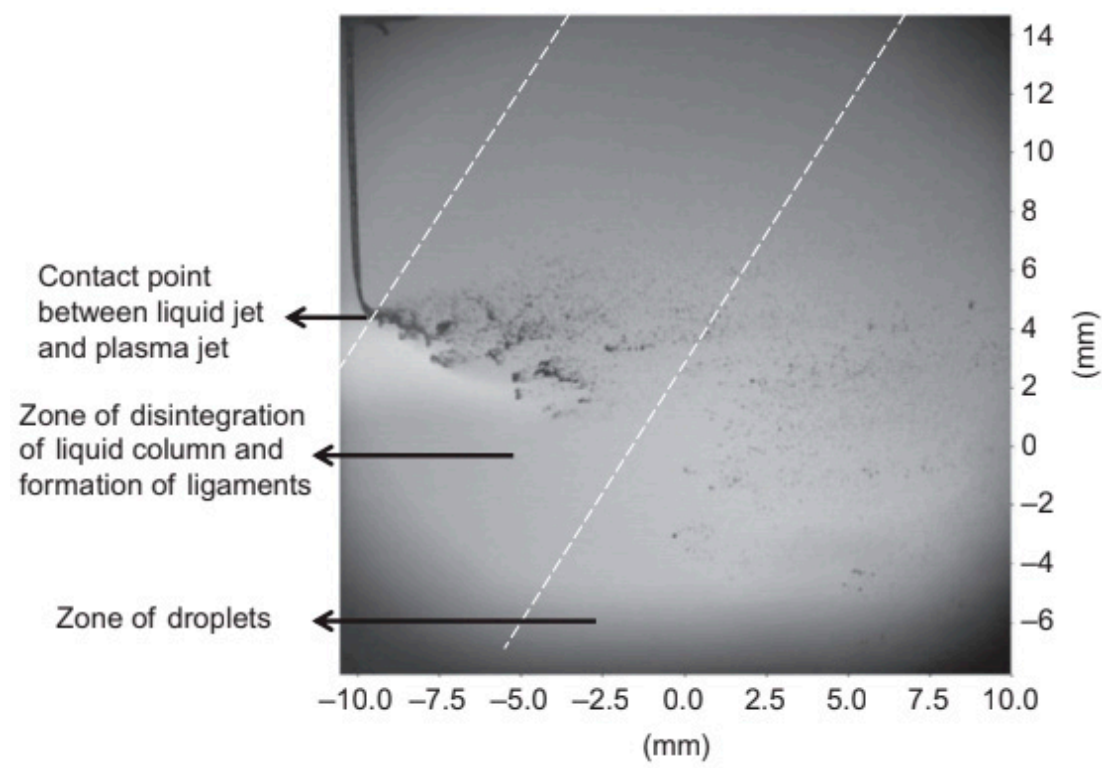

Figure 6. Aerodynamic interactions between the liquid stream and the high-temperature jet. Reproduced with permission from [32].

Figure 5B describes an atomizing injector which utilizes an atomizing gas to provide pressure on the solution precursor in order to break it up into small droplets. These atomized droplets, 2-100 microns in size, penetrate into the plasma jet core inducing an immediate thermal reaction of the solute due to fast evaporation of the solvent $[17,33]$. The direct contact of the atomized solution droplets into the hot plasma core result in the rapid formation of the LSM coatings, indicating a crystalline $\mathrm{La}_{0.5} \mathrm{Sr}_{0.5} \mathrm{MnO}_{3}$ perovskite phase. The XRD spectra of the LSM coatings shows broadened peaks because of the low peak-to-noise ratio of the deposits due to their small crystallite sizes associated with the breakup of the solution precursor into finer droplet sizes [24]. However, the size distribution of the droplets in this type of injector still depends in the nozzle geometry, the gas velocity and flow rate, and the property of the solvents used.

The solution precursor can be delivered into the plasma jet by axial or radial direction [33]. In axial injection, the droplet enters directly into the high-temperature plasma core where the solvent starts to evaporate rapidly, that results in the solute concentration near the droplet surface. This injection mode allows solute saturation in a short period of time. Due to the rapid heating process in axial injection the 
solution precursor droplet can undergo full pyrolization resulting in a dense coating formation [33]. Metcalfe et al., [31] studied the deposition of a Ni-YSZ cermet coating by axial injection with varying torch power. The authors reported a decrease of the nickel content in the composite coatings as the torch power decreased. This could result from the fast evaporation of nickel metal (boiling point at $2732.0^{\circ} \mathrm{C}$ ) [31].

With radial injection of the solution precursor the heating process is much slower compared to the axial one. The droplets interact first with the outer part of the plasma region, which is colder than the plasma core. This injection method is useful for large droplet sizes which may penetrate easier into the jet $[17,18,33]$. The study of Michaux [34] demonstrated the formation of Ni-based cermets with YSZ by SPPS using radial injection. It showed the homogeneous distribution of NiO in the YSZ matrix having a fine microstructure that could be induced by efficient internal circulation of the solvent in the droplets and by rapid diffusion of heat within the droplet.

\subsection{Phenomena in Flight}

Different phenomena occur when the injected solution makes contact with the plasma jet, as discussed in many studies [17,22,35-37], are presented in this section in a chronological way. Initially, the liquid stream or large droplets break-up into small droplets due to the strong shear stress of the plasma flow [36]. After the break-up, the fragmented droplets experience rapid solvent evaporation and the increase of solute concentration follows. The precipitation inside of liquid droplets leads to the solid particle formation prior to coating deposition. The droplets may undergo volumetric or surface precipitation. Fine droplets tend to precipitate volumetrically, which is also known as homogeneous nucleation, which results in splat formation. On the other hand, larger droplets tend to precipitate superficially resulting in shell formation. If the solid shell is impermeable, internal pressurization takes place leading to the shell fracture. This may lead to the formation of cracked shells. The cracked shell may become molten and form spherical particles, as shown in Figure 7. The different particle morphologies formed by SPPS have been discussed in the work of Saha et al. [35]. Ozturk et al. [37] modeled the formation of the solid crust at precipitation occurring in a single droplet. The solid particles undergo heating and melting depending on their residence time inside the plasma jet. The evaporation from the molten solid may take place. The vapors may condense and form the nanoparticles.

Figure 8 is a high magnification micrograph of the surface of an SPPS Zn-HA coating showing the different particles formed in-flight deposited onto the substrate. The chemical phenomena of the solution occurring in-flight can be experimentally tested under equilibrium conditions with the use of thermogravimetric-differential thermal analyzer (DTA-TGA). In general, the chemical reactions start with the evaporation of solvent, pyrolysis of the precursor, and crystallization or oxidation of the precursor $[27,28,38]$.

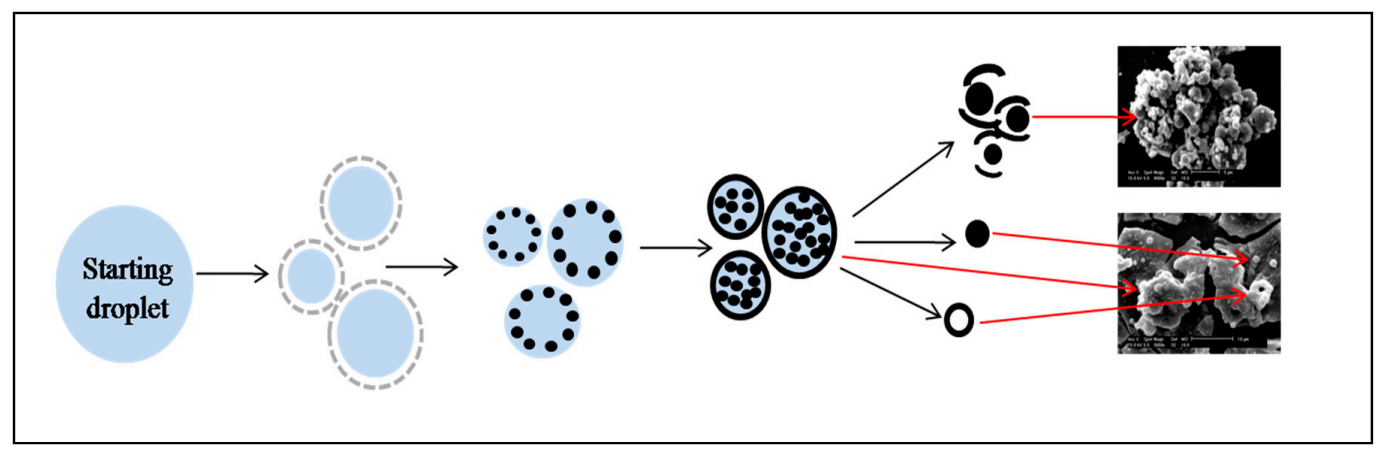

Figure 7. Possible route of particle formation in the SPPS process. Reproduced with permission from [39], Elsevier, 2017. 


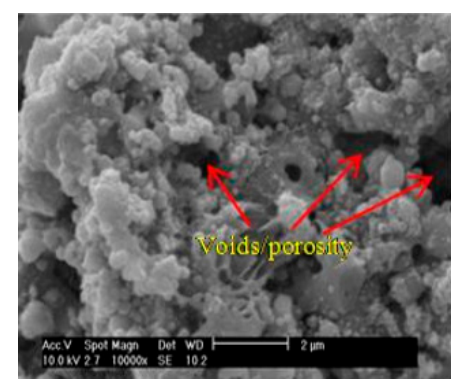

Figure 8. Surface micrograph of Zn-HA coating showing the different particle morphologies present like fine spheres, fragmented shells, and agglomerates. Reproduced with permission from [13], Elsevier, 2018.

Michaux et al. [34] identified the sequence of chemical reaction in the fabrication of $\mathrm{NiO} / 8 \mathrm{YSZ}$ cermet:

- The exothermic reaction occurs first around $100{ }^{\circ} \mathrm{C}$ corresponding to ethanol solvent evaporation.

- The endothermic peak at $300{ }^{\circ} \mathrm{C}$ corresponded to decomposition of nitrate precursors.

- The endothermic peak at around $400^{\circ} \mathrm{C}$ indicated the oxidation of precursors forming $\mathrm{NiO}$ doped with YSZ.

\subsection{Cermet Coatings Formation}

The microstructure of the sprayed cermet depends on the in-flight phenomena of the plasma jet discussed above. The particles arriving on the substrate or previously-deposited coating generally have sizes in the sub-micrometer or nanometer range [40,41]. To understand the coating formation, the deposits obtained from a single torch scan, as shown in Figure 9, can be studied [41].

Figure 9a shows deposited melted or partially melted spherical particles ( $0.3 \mu \mathrm{m}$ in diameter), which resulted from the evaporation of solvent at the surface of the small droplets $[33,35,41]$. The small sintered particles $(\sim 1 \mu \mathrm{m})$ are like the melted ones, but deposited before melting occurs, as shown in Figure $9 b[33,35,37,41]$. These small particles could have stuck together forming agglomerates as it reaches the substrate, as shown in Figure 9c. Such particles are the major deposit elements of the coating microstructure which contributes to the small pores in the coating [41]. The large pores in coatings due to the stacking of irregularly shaped agglomerates, such as dome-like ones, are shown in Figure 10 [39].
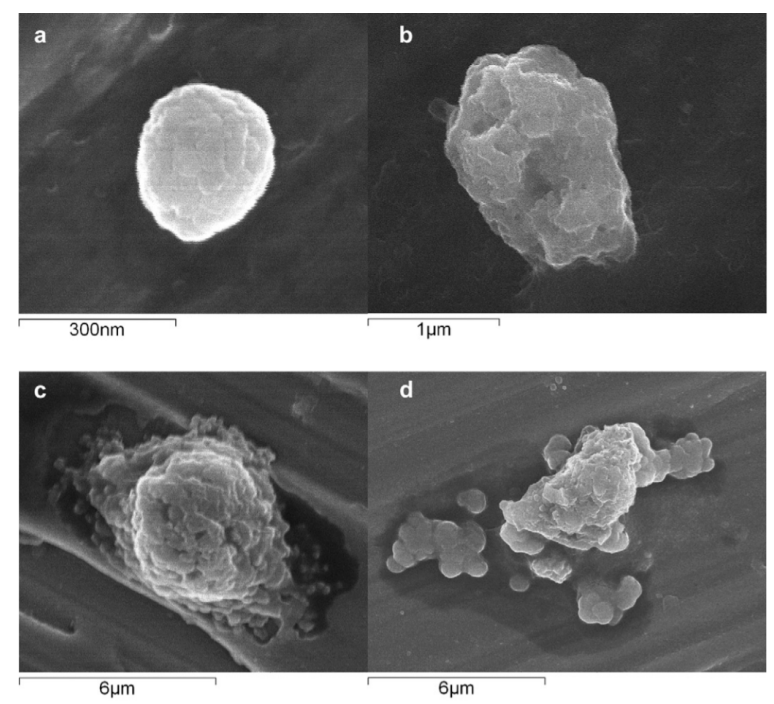

Figure 9. Cont. 


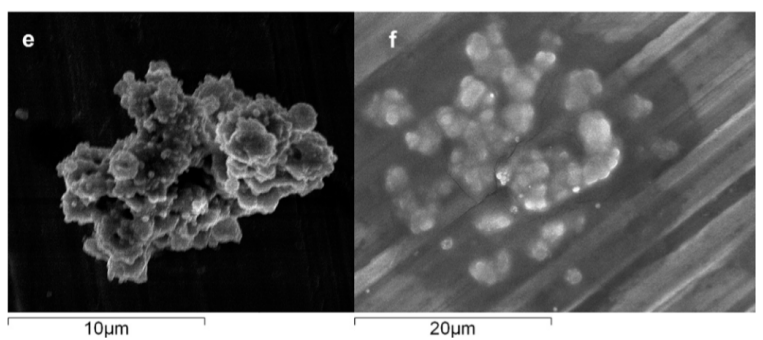

Figure 9. Typical LSM deposits collected on the substrate at the distance $60 \mathrm{~mm}(\mathbf{a}, \mathbf{b})$ and $70 \mathrm{~mm}(\mathbf{c}-\mathbf{f})$ from the plasma torch exit in the single scan experiments. Reproduced with permission from [41], Elsevier, 2013.

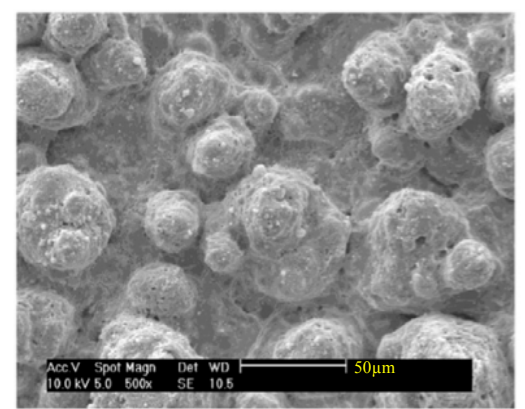

(a)

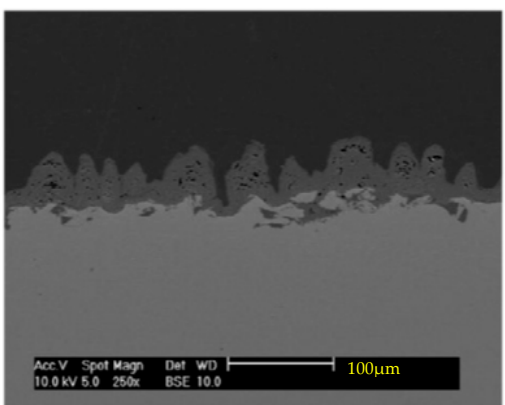

(b)

Figure 10. SEM images at the (a) surface and (b) cross-section of HA coating from low concentration solution showing a dome-like microstructure. Reproduced with permission from [39], Elsevier, 2017.

On the other hand, the wet agglomerates depicted in Figure $9 \mathrm{~d}$ are some droplets entrained in the cold region of the plasma jet which experienced less heating and only partial pyrolization before impact. They may contribute in formation of a sponge-like structure, as reported by Wang et al. [24]. Figure 9e also shows the wet agglomerates formed with less amount of solvent. This type of deposit is formed through continuous evaporation of the solvent when vapors escaped by fine pores between small particles when impacting the substrate. Finally, the solution droplets that bounced away from the plasma core without experiencing effective heating are shown in Figure 9f. These wet droplets could have been generated by larger solution droplets which undergo in situ pyrolization after impacting the substrate's surface [41].

\section{Microstructure of Cermet Coatings}

Microstructure is an important factor determining the final properties of solution plasma sprayed coatings. The microstructure results from impact of the different particles on the substrate or previously deposited coating, namely: (i) melted particles; (ii) small sintered particles; (iii) dry agglomerates; (iv) wet agglomerates; and, (v) wet droplets, as described in many papers $[17,22,40]$.

Unlike in conventional plasma spraying (APS), where large splats are formed, SPPS-prepared coatings exhibit many different microstructural features. The APS-deposited Ni-YSZ (see Figure 11) cermet coating cross-section shows a porous lamellar microstructure with voids and unmelted particles [42]. 


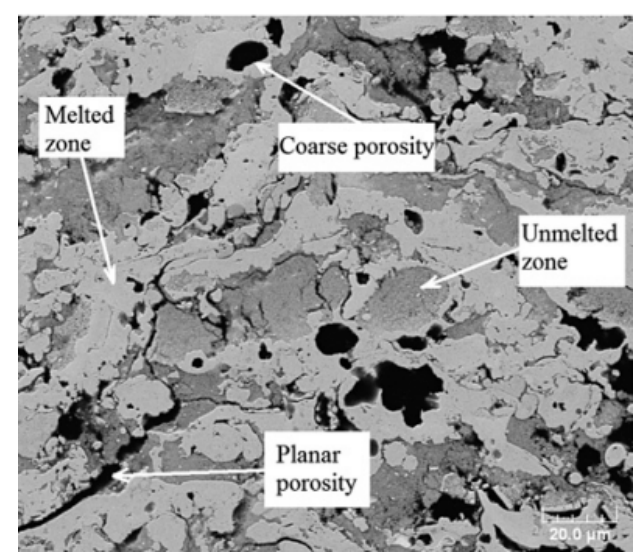

Figure 11. SEM cross-sectional microstructure of Ni-YSZ by APS. Reproduced with permission from [42], Elsevier, 2008.

On the contrary, uniformly dense microstructures with fine-scale porosity characterize the SPPS-deposited Ni-YSZ cermet coatings as reported by Michaux et al. [34]. Wang and Coyle [23] also reported that Ni-YSZ cermet coatings containing spherical YSZ particles of about $0.5 \mu \mathrm{m}$ in diameter were held together by a continuous Ni matrix. The strong bonding between particles due to the continuous Ni matrix could improve the mechanical properties of the coating. Consequently, there are no studies yet on the investigation of the mechanical properties of cermet coatings deposited using the SPPS process.

Candidato et al. [13], reported that microstructures of both HA and Zn-doped HA coatings deposited under similar conditions showed the presence of agglomerated fine spherical particles and melted particles at the surface, which are characteristics of SPPS coatings. However, the cross-section of the $\mathrm{Zn}$-doped HA cermet coating seems to be denser compared to the un-doped HA (Figure 12).

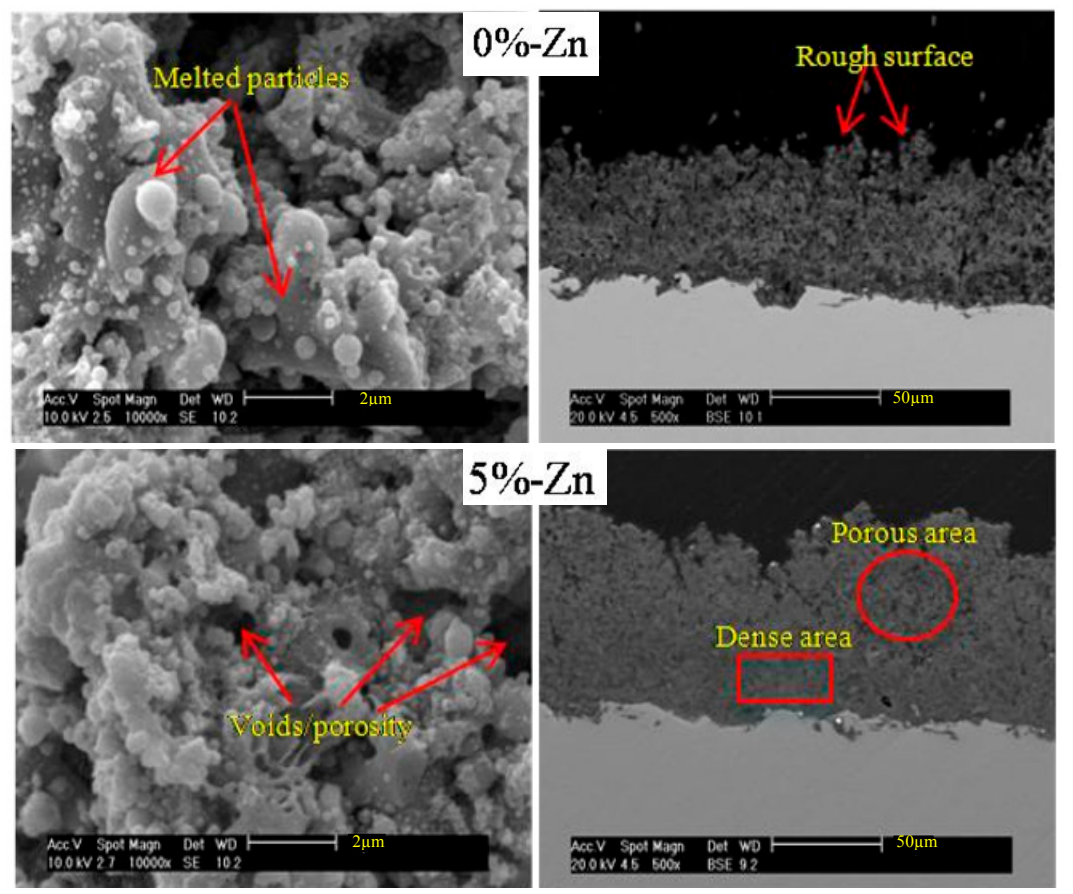

Figure 12. SEM images at the (left) surface and (right) cross-section of the coatings of $(0 \%-\mathrm{Zn})$ un-doped HA and (5\%-Zn) Zn-doped HA. Reproduced with permission from [13], Elsevier, 2018. 
Additionally, Nishida (2009) reported that the addition of nickel particles into samaria-doped ceria modifies the microstructure of coating from including only spherical particles into the one with nano-spheres with embedded nanoparticles to be used in SOFC applications [43]. A porous microstructure with porosity in the form of interconnected networks of voids was observed for cermet coatings produced from an aqueous solution precursor [29]. The void in the coating's architecture is a result from the decomposition of the partially pyrolyzed precursor which is submitted to in situ evaporation of the remaining solvent [44]. Figure 13 displays the surface morphology of the LSM cermet coating deposited using (Figure 13a) water and (Figure 13b) ethanol as solvents. The aqueous SPPS coating shows a porous sponge-like morphology with agglomerated solid $(\sim 0.5 \mu \mathrm{m})$ particles. On the other hand, ethanol SPPS coating shows similar porous morphology and agglomerated solid particles, but with the refinement of particle size $(\sim 0.2 \mu \mathrm{m})$ which attributed the increase of the triple phase boundary length between the YSZ and LSM cathode, decreasing cathode polarization.
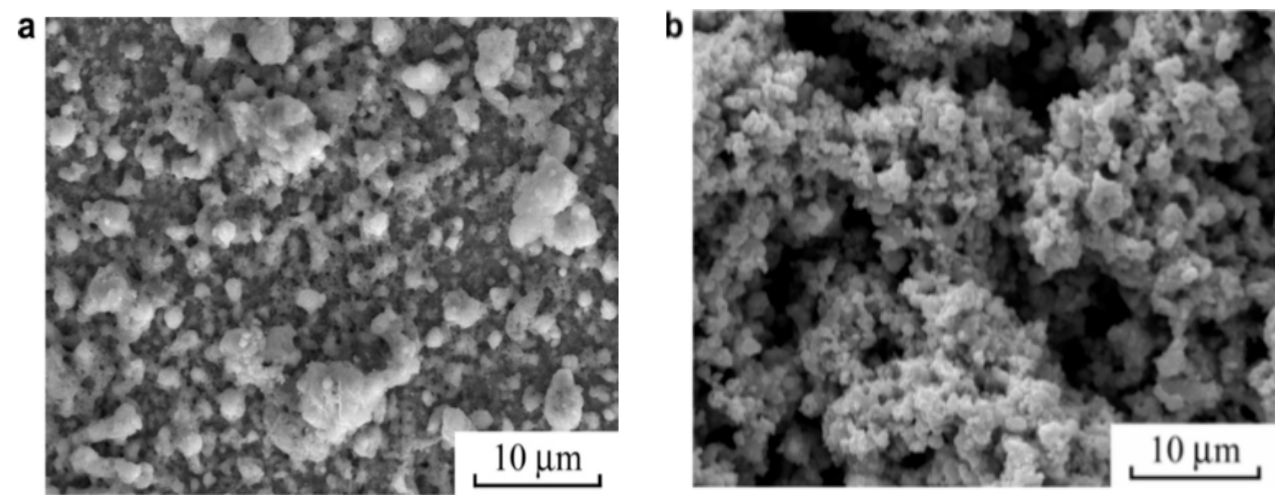

Figure 13. Surface morphology of an LSM cermet cathode deposited by (a) aqueous solution (reproduced with permission from [24], Elsevier, 2011) and (b) ethanol (reproduced with permission from [29], Elsevier, 2012) SPPS.

As discussed in the previous sections, the chemistry of the initial precursors influences the microstructure of the final cermet coatings, as depicted in Figure 14, showing the SEM images of nickel-based cermets (a) Ni-YSZ and (b) Ni-SDC. Nickel-samaria-doped ceria (Ni-SDC) coating displays a microstructure composed of very fine spherical particles having micrometer and nanometer sizes similar to nickel-yttria-stabilized zirconia. The morphology of nickel particles in SPPS was already reported to be very fine, which suggests that its combination with samaria-doped ceria (SDC) does not promote the growth acceleration of the particles [26].
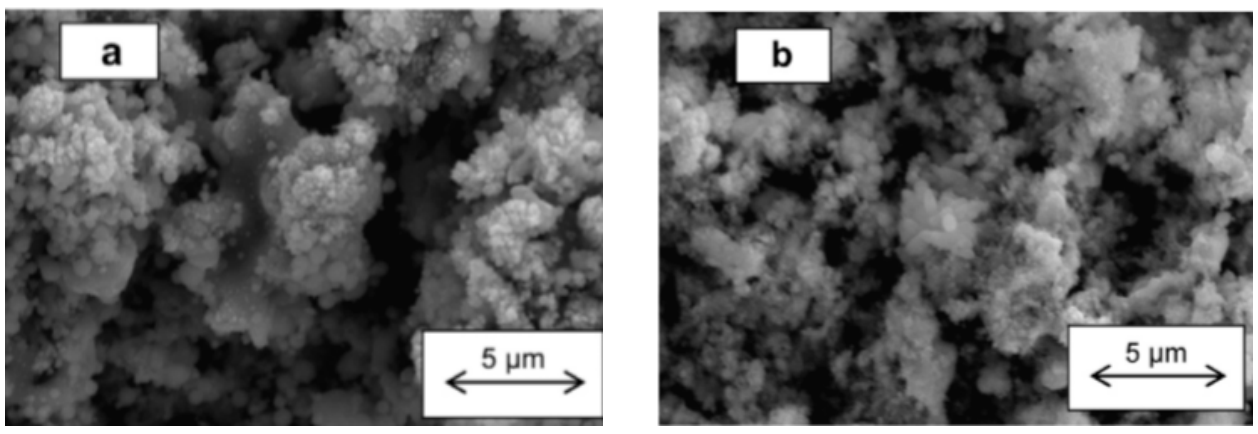

Figure 14. Scanning electron micrographs of (a) Ni-YSZ and (b) Ni-SDC SPPS cermet coatings. Reproduced with permission from [26], Elsevier, 2012. 
Due to the complex in-flight phenomena and the unique particle morphologies formed during the process, some interesting coatings' microstructures and architectures can be generated in SPPS depending on the set of parameters used [26,33,34,42,45-47]. Lay et al. [45] reported on the deposition of Ni-SDC using different spray parameters (SP), namely, SP1, which has higher velocity, energy, and solution precursor flow rate compared to SP2. The latter has a lower solution concentration. Ni-SDC using SP1 displays poorly-adhered finer particles with greater porosity compared to SP2 (see Figure 15). The surface morphology of Ni-SDC, obtained using SP1, shows no splat-shaped microstructural features which indicates that partial pyrolization of droplets takes place in the plasma jet due to low solution concentration and higher plasma energy than SP2 with high solution concentration. Thus, evaporation of most elements in the plasma, and subsequent nucleation at the surface of the substrate, is highly possible leading to the deposition of less-adhering coatings.
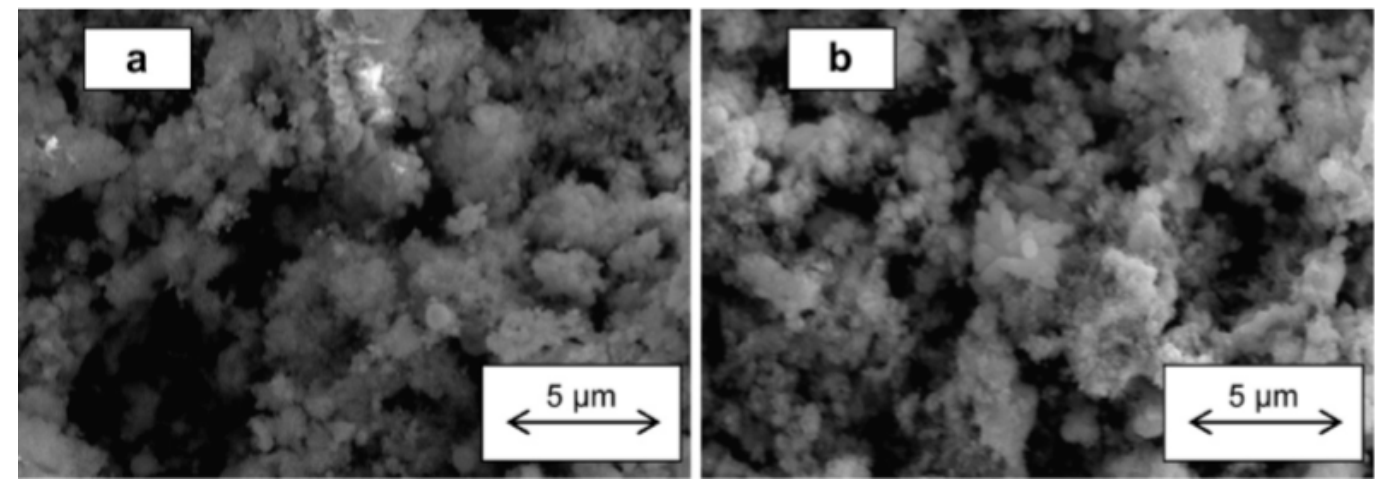

Figure 15. Surface morphologies of Ni-SDC cermet coatings using (a) SP1 and (b) SP2. Reproduced with permission from [45], ELECTROCHEMICAL SOCIETY, 2011.

Moreover, the injection of solution precursor into the plasma jet may influence the microstructure of the cermet coatings. The droplets obtained using a mechanical injector had initially large droplets which could have undergone secondary break-up to form finer droplets as discussed in Section 2.2 [17,22,23,32]. Consequently, the resulting microstructure of coatings sprayed using mechanically-injected solution shows a porous, agglomerated, dome-like structure with resolidified particles at the surface [23]. The injection by atomization produces about 2-100 micron droplets, which may undergo rapid evaporation. Consequently, the complete pyrolysis of the solute particles may occur at the interaction with the plasma jet $[17,33,34]$. The injection by atomization leads to the formation of irregular tower-like agglomerates of very fine particles with smooth surface deposits, as reported elsewhere [34].

On the other hand, the long interaction time between the solution precursor droplets and the plasma jet during the trajectory induces the effects of sintering and of local re-melting. Michaux et al. [34] reported porous architectures with voids for external/radially delivered Ni-YSZ cermet due to stacking of partially-molten splats forming cavities [34]. On the other hand, dense uniform-layered coating with fine-scale porosity were observed for the solution precursor introduced within the torch convergence tube, which is attributed to the faster heating of the droplet leading to complete pyrolysis (see Figure 16) [31]. Therefore, the microstructure of the ceramic-metal composite coatings can be influenced by the way of injection depending on the foreseen application. 


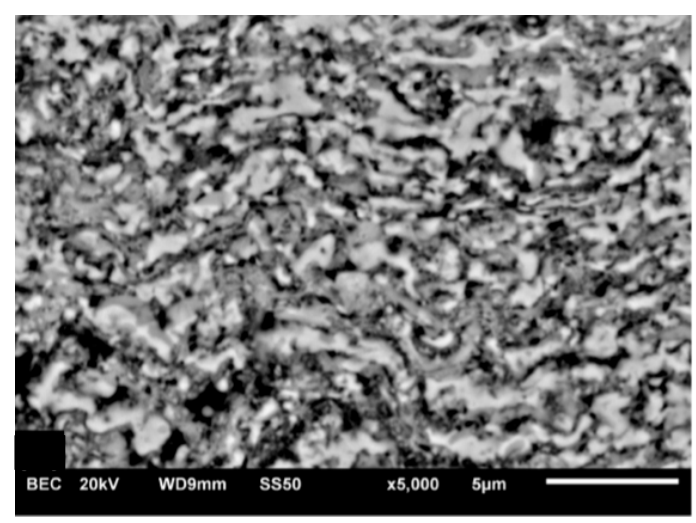

Figure 16. Cross-section of the Ni-YSZ anodes deposited via internal and axial injectors. Reproduced with permission from [31], Elsevier, 2014.

\section{Applications of SPPS Cermet Coatings}

SPPS cermet coatings have a wide variety of potential and emerging applications. However, plasma spraying of ceramic-metal composite solution precursor is still in its development stage, this review presents an overview of some of the SPPS cermet applications as protective and performance-enhancing coatings.

\subsection{Solid Oxide Fuel Cells (SOFC)}

Cermet coatings deposited using the SPPS process have primarily been used as electrodes in SOFC applications. Strontium-doped lanthanum manganite (LSM) as a cathode and nickel-Yttria stabilized zirconia (Ni-YSZ) as an anode are ones that have been extensively studied [23-26,29,31,34,41-43,45-48]. Wang et al. [24,29] investigated the polarization of LSM SOFC cathode material deposited using water and ethanol as solvent, respectively. The polarization of the cathode at $1000{ }^{\circ} \mathrm{C}$ gives the lowest specific surface resistance that reached $0.15 \Omega \cdot \mathrm{cm}^{2}$ for an alcohol SPPS LSM cathode, which is half of the polarization of the aqueous SPPS LSM cathode, which is $0.3 \Omega \cdot \mathrm{cm}^{2}$. This decrease in cathode polarization using ethanol is influenced by the increase of the triple phase boundary (TPB), i.e., associated with its catalytic property of the coating which is also related to the microstructure of the coating, as discussed in Section $3[19,46,48]$.

Another study by Li et al. [25] reported a low polarization of SOFC cathode of $0.07 \Omega \cdot \mathrm{cm}^{2}$ at $900{ }^{\circ} \mathrm{C}$ using strontium-doped samarium cobaltite perovskite sprayed using a stand-off of $130 \mathrm{~mm}$. The long dwell time of droplets resulted in the complete reaction of the precursor and in fine microstructures of the perovskite phase. The Ni-YSZ composite anode studied by the SPPS process shows that the performance of this type of electrode is influenced by the spray parameters, such as the solution composition, plasma gas composition, and the stand-off distance [34]. Metcalfe et al., [31] reported one of the highest power densities of $0.45 \mathrm{~W} / \mathrm{cm}^{2}$ at $0.7 \mathrm{~V}$ and an open circuit potential of $1.05 \mathrm{~V}$ at $750{ }^{\circ} \mathrm{C}$ thanks to the use of concentrated citric acid as an additive. Wang et al. [23] studied the electrical resistance of Ni-YSZ coatings at different temperatures which shows a decrease in the inverse of the electrical resistance with increasing temperature confirming the existence of continuous network of $\mathrm{Ni}$ in the coating [23].

The increase of spray distance and variation of plasma working gas mixtures modified the coatings microstructures [34]. Further works are still underway to better understand the electrochemical properties of SOFCs.

\subsection{Catalyst}

Cermet photocatalysts by SPPS were rarely investigated. Dom et al. [10] demonstrates SPPS deposition of porous films of pure spinel zinc-ferrite phases with a band gap of $\sim 1.9 \mathrm{eV}$ which favors 
the degradation of methylene blue pollutant under solar radiation. Figure 17 shows the substantial increase of photo-degradation efficiency $\eta$ of SPPS zinc ferrite films with increasing film thickness from $25 \mu \mathrm{m}$ to $50 \mu \mathrm{m}$. Although it is not comparable for the powder catalyst from solid state reaction routes, SPPS zinc ferrite films still demonstrate their potential in photocatalysis applications. Exploration of the SPPS process with appropriate controls on the critical spray parameters to produce new photocatalytic coatings has been taken into account in order to have niche applications.

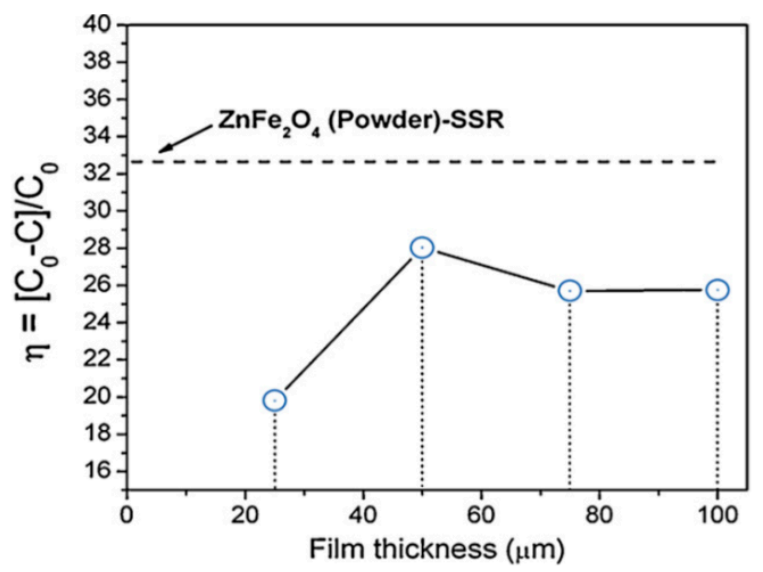

Figure 17. Methylene blue photo de-coloration efficiency versus $\mathrm{ZnFe}_{2} \mathrm{O}_{4}$ film thickness for films deposited at precursor $\mathrm{pH}=8$. The dotted horizontal line represents the efficiency of powder $\mathrm{ZnFe}_{2} \mathrm{O}_{4}$ photocatalyst synthesized by a solid state reaction. Reproduced with permission from [10], Elsevier, 2012.

\subsection{Biomedical Coatings}

Biomedical coatings have been utilized to promote bone growth at the surface of implants [13,15,39]. These coatings are deposited by an FDA-approved process, i.e., atmospheric plasma spraying [20]. Generally, the bioceramic coatings have limited use because of their low mechanical strength. Hence, by reinforcing the metal particles in the ceramic-based matrix forming the cermet coating enhances the strength, i.e., the fracture toughness and the wear resistance of the coatings for load-bearing applications $[19,20]$. Cermet coatings containing metal particles of zinc, silver, and copper do not only improve the mechanical strength of the coatings, but may promote antibacterial properties [13]. A study of Candidato et al. [13] has successfully produced zinc-doped hydroxyapatite coatings using the SPPS process. The microstructure of the coatings transforms from a highly porous coating to a dense one by adding zinc to the hydroxyapatite matrix (see Figure 12). It was also reported that increasing the zinc concentration on the cermet coatings inhibits the formation of the hydroxyapatite phase. The optimal $\mathrm{Zn}$ content for $\mathrm{Zn}-\mathrm{HA}$ coatings is $5 \%$.

Sanpo et al. [15] reported the SPPS deposition of cobalt ferrite coatings for biomedical applications [15]. In their study, the phase content and the cermet coating microstructure were greatly influenced by the chelating agent used. As-sprayed cobalt ferrite coating shows incomplete pyrolysis of the splats with a larger amount of other oxide phases. With the addition of citric acid as a chelating agent, the formation of $90 \%$ cobalt ferrite phase was achieved and fully-melted splats were observed. In fact, the chelating agents could have helped in the homogeneous interaction of mineral ions preventing the undesirable spontaneous condensation of cobalt and iron cations [14-16].

With these promising results, cermet coatings under the SPPS process are also a viable candidate for biomedical application. However, evaluation on the biological properties of the cermet coatings by SPPS is yet to be done.

Author Contributions: L.P. initiated this review article. R.C.J., R.U. and L.P. conceptualized the flow and contents of this review. R.U. gathered the necessary literatures for the article and wrote the body of the review paper. R.C.J. 
helped on the abstract and subsections of the paper. L.P. contributes on correcting the technical aspect of the review article.

Acknowledgments: Romnick Unabia would like to acknowledge the Department of Science and TechnologyAccelerated Science and Technology Human Resource Development Program (DOST-ASTHRDP) for the scholarship grant, and Department of Science and Technology- Philippine Council for Industry, Energy and Emerging Technology Research and Development (DOST-PCIEERD) for the financial grant.

Conflicts of Interest: The authors declare no conflict of interest.

\section{Symbol}

$\begin{array}{ll}\rho & \text { Density of the fluid } \\ L_{v} & \text { Latent heat of vaporization, } \mathrm{J} \cdot \mathrm{kg}^{-1} \\ \Omega & \text { Ohm } \\ \eta & \text { Photo-degradation efficiency, \% } \\ c_{p} & \text { Specific heat, } \mathrm{J} \cdot \mathrm{kg}^{-1} \cdot \mathrm{K}^{-1} \\ \sigma_{s} & \text { Surface tension, } \mathrm{J} / \mathrm{m}^{2} \\ T_{v} & \text { Vaporization temperature, } \mathrm{K} \\ v^{2} \text { solution } & \text { Velocity of the solution } \\ v_{\text {plasma }}^{2} & \text { Velocity of the plasma gas } \\ \mu_{s} & \text { Viscosity, Pa } \cdot \mathrm{s}\end{array}$

\section{Abbreviations}

$\begin{array}{ll}\text { APS } & \text { Atmospheric plasma spray } \\ \text { CZP } & \text { Calcium zinc phosphate } \\ \text { DTA-TGA } & \text { Thermogravimetric-differential thermal analyzer } \\ \text { FDA } & \text { Food and Drugs Administration } \\ \text { HA } & \text { Hydroxyapatite } \\ \text { LSM } & \text { Strontium-doped lanthanum manganite } \\ \text { Ni-SDC } & \text { Nickel samaria-doped ceria } \\ \text { Ni-YSZ } & \text { Nickel Yttria stabilized zirconia } \\ \text { SOFC } & \text { Solid oxide fuel cells } \\ \text { SP } & \text { Spray parameters } \\ \text { SPPS } & \text { Solution precursor plasma spray } \\ \text { SPS } & \text { Suspension plasma spray } \\ \text { TCP } & \text { Tri-calcium phosphate } \\ \text { TPB } & \text { Triple phase boundary } \\ \text { Zn-HA } & \text { Zinc-doped Hydroxyapatite }\end{array}$

\section{References}

1. Ageorges, H.; Ctibor, P.; Medarhri, Z.; Touimi, S.; Fauchais, P. Influence of the metallic matrix ratio on the wear resistance (dry and slurry abrasion) of plasma sprayed cermet (chromia/stainless steel) coatings. Surf. Coat. Technol. 2006, 201, 2006-2011. [CrossRef]

2. Basak, A.K.; Achanta, S.; Celis, J.P.; Vardavoulias, M.; Matteazzi, P. Structure and mechanical properties of plasma sprayed nanostructured alumina and FeCuAl-alumina cermet coatings. Surf. Coat. Technol. 2008, 202, 2368-2373. [CrossRef]

3. Xu, J.; Zou, B.; Zhao, S.; Hui, Y.; Huang, W.; Zhou, X.; Wang, Y.; Cai, X.; Cao, X. Fabrication and properties of $\mathrm{ZrC}-\mathrm{ZrB}_{2} / \mathrm{Ni}$ cermet coatings on magnesium alloy by atmospheric plasma spraying of SHS powders. Ceram. Int. 2014, 40, 15537-15544. [CrossRef]

4. Zhao, D.; Luo, F.; Zhou, W.; Zhu, D. Effect of critical plasma spray parameters on the complex permittivity and microstructure by plasma spraying $\mathrm{Cr} / \mathrm{Al}_{2} \mathrm{O}_{3}$ coatings. Appl. Surf. Sci. 2013, 264, 545-551. [CrossRef]

5. Deen, K.M.; Afsal, M.; Lui, Y.; Farooq, A.; Ahmad, A.; Asselin, E. Improved corrosion resistance of air plasma sprayed WC-12\%Co cermet coating by laser re-melting process. Mater. Lett. 2017, 191, 34-37. [CrossRef]

6. Zhu, H.B.; Li, H.; Li, Z.X. Plasma sprayed $\mathrm{TiB}_{2}-\mathrm{Ni}$ cermet coatings: Effect of feedstock characteristics on the microstructure and tribological performance. Surf. Coat. Technol. 2013, 235, 620-627. [CrossRef] 
7. Li, C.J.; Li, C.X.; Xing, Y.; Xie, Y.; Long, H. Influence of characteristics of stabilized zirconia electrolyte on performance of cermets supported tubular SOFCs. Rare Met. 2006, 25, 273-279. [CrossRef]

8. Li, C.J.; Li, C.X.; Xing, Y.Z.; Gao, M.; Yang, G.J. Influence of YSZ electrolyte thickness on the characteristics of plasma-sprayed cermet supported tubular SOFC. Solid State Ion. 2006, 177, 2065-2069. [CrossRef]

9. Li, C.X.; Li, C.J.; Guo, L.J. Effect of composition of NiO/YSZ anode on the polarization characteristics of SOFC fabricated by atmospheric plasma spraying. Int. J. Hydrog. Energy 2010, 35, 2964-2969. [CrossRef]

10. Dom, R.; Sivakumar, G.; Hebalkar, N.Y.; Joshi, S.V.; Borse, P.H. Deposition of nanostructured photocatalytic zinc ferrite films using solution precursor plasma spraying. Mater. Res. Bull. 2012, 47, 562-570. [CrossRef]

11. Watanabe, M.; Yamashita, H.; Chen, X.; Yamanaka, J.; Kotobuki, M.; Suzuki, H.; Uchida, H. Nano-sized Ni particles on hollow alumina ball: Catalysts for hydrogen production. Appl. Catal. B Environ. 2007, 71, 237-245. [CrossRef]

12. Li, X.; Ma, W.; Wen, J.; Bai, Y.; Sun, L.; Chen, B.; Dong, H.; Shuang, Y. Preparation of $\mathrm{SrZrO}_{3}$ Thermal Barrier Coating by Solution Precursor Plasma Spray. J. Therm. Spray Technol. 2017, 26, 371-377. [CrossRef]

13. Candidato, R.; Sergi, R.; Jouin, J.; Noguera, O.; Pawlowski, L. Advanced microstructural study of solution precursor plasma sprayed Zn doped hydroxyapatite coatings. J. Eur. Ceram. Soc. 2018, 38, 2134-2144. [CrossRef]

14. Sanpo, N.; Ang, A.S.M.; Hasan, F.; Wang, J.; Berndt, C. Phase and Microstructures of solution precursor plasma sprayed cobalt ferrite splats. In Proceedings of the 5th Asian Thermal Spray Conference, Tsukuba, Japan, 26-28 November 2012; pp. 145-146.

15. Sanpo, N.; Berndt, C.; Ang, A.S.M.; Wang, J. Effects of the chelating agent contents on the topography, composition, and phase of SPPS-deposited cobalt ferrite splats. Surf. Coat. Technol. 2013, 232, 247-253. [CrossRef]

16. Sanpo, N.; Wang, J.; Ang, A.S.M.; Berndt, C. Influence of the different organic chelating agents on the topography, physical properties and phase of SPPS-deposited spinel ferrite splats. Appl. Surf. Sci. 2013, 284, 171-178. [CrossRef]

17. Pawłowski, L. Suspension and Solution Thermal Spray coatings. Surf. Coat. Technol. 2009, 203, $2807-2829$. [CrossRef]

18. Killinger, A.; Gadow, R.; Mauer, G.; Guignard, A.; Vaben, R.; Stover, D. Review of new developments in suspension and solution precursor thermal spray processes. J. Therm. Spray Technol. 2011, 20, 677-695. [CrossRef]

19. Brinley, E.; Babu, K.S.; Seal, S. The Solution Precursor Plasma Spray Processing of Nanomaterials. JOM 2007, 59, 54-59. [CrossRef]

20. Keshri, A.K.; Agarwal, A. Plasma Processing of Nanomaterials for Functional Applications-A Review. Nanosci. Nanotechnol. Lett. 2012, 4, 228-250. [CrossRef]

21. Karthikeyan, J.; Berndt, C.C.; Tikkanen, J.; Wang, J.Y.; King, A.H.; Herman, H. Preparation of nanophase materials by thermal spray processing of liquid precursors. NanoStruct. Mater. 1997, 9, 137-140. [CrossRef]

22. Pawłowski, L. Application of solution precursor spray techniques to obtain ceramic films and coatings. Future Dev. Therm. Spray Coat. 2015, 123-141. [CrossRef]

23. Wang, Y.; Coyle, T.W. Solution Precursor Plasma Spray of Nickel-Yttria Stabilized Zirconia anodes for solid fuel cell application. J. Therm. Spray Technol. 2007, 16, 898-904. [CrossRef]

24. Wang, X.; Li, C.X.; Li, C.J.; Tian, L.; Yang, G. Microstructure and Electrochemical Behavior of $\operatorname{La}_{0.8} \mathrm{Sr}_{0.2} \mathrm{MnO}_{3}$ deposited by Solution Precursor Plasma Spraying. Rare Met. Mater. Eng. 2011, 40, 1881-1886. [CrossRef]

25. Li, C.X.; Liu, S.; Zhang, Y.; Li, C.J. Characterization of the microstructure and electrochemical behavior of $\mathrm{Sm}_{0.7} \mathrm{Sr}_{0.3} \mathrm{Co}_{3}-\delta$ cathode deposited by solution precursor plasma spraying. Int. J. Hydrog. Energy 2012, 37, 13097-13102. [CrossRef]

26. Lay, E.; Metcalfe, C.; Kesler, O. The influence of incorporating MgO into Ni-based cermets by plasma spraying on anode microstructural and chemical stability in dry methane. J. Power Sources 2012, 218, 237-243. [CrossRef]

27. Chen, D.; Jordan, E.H.; Gell, M. Effect of solution concentration on splat formation and coating microstructure using the solution precursor plasma spray process. Surf. Coat. Technol. 2008, 202, 2132-2138. [CrossRef]

28. Chen, D.; Jordan, E.H.; Gell, M. The Solution Precursor Plasma Spray Coatings: Influence of Solvent type. Plasma Chem. Plasma Process. 2010, 30, 111-119. [CrossRef] 
29. Wang, X.; Li, C.X.; Li, C.J.; Yang, G.J. Microstructure and polarization of $\mathrm{La}_{0.8} \mathrm{Sr}_{0.2} \mathrm{MnO}_{3}$ cathode deposited by alcohol solution precursor plasma spraying. Int. J. Hydrog. Energy 2012, 37, 12879-12885. [CrossRef]

30. Fauchais, P.; Vardelle, A. Innovative and emerging processes in plasma spraying: From micro- to nano-structured coatings. J. Phys. D Appl. Phys. 2011, 44, 194011. [CrossRef]

31. Metcalfe, C.; Grindler, E.L.; Kesler, O. Characterization of Ni-YSZ anodes for solid oxide fuel cells fabricated by solution precursor plasma spraying with axial feedstock injection. J. Power Sources 2014, 247, 831-839. [CrossRef]

32. Marchland, C.; Mariaux, G.; Vardelle, M.; Vardelle, A. Injection and Aerodynamic Fragmentation of Liquid Precursors under Plasma Spray Conditions. In Proceedings of the 2nd International Workshop on Suspension and Solution Thermal Spraying, Tours, France, 5-7 June 2008.

33. Ozturk, A.; Cetegen, B. Modeling of axially and transversely injected precursor droplets into a plasma environment. Int. J. Heat Mass Transf. 2005, 48, 4367-4383. [CrossRef]

34. Michaux, P.; Montavon, G.; Grimaud, A.; Denoirjean, A.; Fauchais, P. Elaboration of Porous NiO/8YSZ Layers by several SPS and SPPS routes. J. Therm. Spray Technol. 2010, 19, 317-327. [CrossRef]

35. Saha, A.; Seal, S.; Cetegen, B.; Jordan, E.; Ozturk, A.; Basu, S. Thermo-physical processes in cerium nitrate precursor droplets injected into high temperature plasma. Surf. Coat. Technol. 2009, 203, 2081-2091. [CrossRef]

36. Sanpo, N. Solution Precursor Plasma Spray System; Springer: New York, NY, USA, 2014; Volume 7, ISBN 9783319070247.

37. Ozturk, A.; Cetegen, B.M. Modelling of plasma assisted formation of precipitates in zirconium containing liquid precursor droplets. Mater. Sci. Eng. A 2004, 384, 331-351. [CrossRef]

38. Xiong, H.; Weiqi, S. Investigation of Droplet Atomization and Evaporation in Solution Precursor Plasma Spray Coating. Coatings 2017, 7, 207. [CrossRef]

39. Candidato, R.; Sokołowski, P.; Pawłowski, L.; Lecomte-Nana, G.; Constantinescu, C.; Denorjean, A. Development of hydroxyapatite coatings by solution precursor plasma spray process and their microstructural characterization. Surf. Coat. Technol. 2017, 318, 39-49. [CrossRef]

40. Fauchais, P.; Vardelle, A. Solution and suspension plasma spraying of nanostructured coatings. Adv. Plasma Spray Appl. 2012, 149-188. [CrossRef]

41. Shan, Y.G.; Wang, Y.L.; Coyle, T. Analysis of deposits formation in plasma spraying with liquid precursors. Appl. Therm. Eng. 2013, 51, 690-697. [CrossRef]

42. Benyoucef, A.; Klein, D.; Coddet, C.; Benyoucef, B. Development and characterization of (Ni-Cu-Co)-YSZ and Cu-Co-YSZ cermets anode materials for SOFC application. Surf. Coat. Technol. 2008, 202, 2202-2207. [CrossRef]

43. Nishida, R.; Kakinuma, K.; Nishino, H.; Kamino, T.; Yamashita, H.; Watanabe, M.; Uchida, H. Synthesis of nickel nanoparticles supported on hollow samaria-doped ceria particles via the solution-spray plasma technique: Anode catalysts for SOFCs. Solid State Ion. 2009, 180, 968-972. [CrossRef]

44. Fauchais, P.; Rat, V.; Coudert, J.F.; Etchart-Salas, R.; Montavon, G. Operating parameters for suspension and solution plasma-spray coatings. Surf. Coat. Technol. 2008, 202, 4309-4317. [CrossRef]

45. Lay, E.; Metcalfe, C.; Kesler, O. Influence of Tertiary Phases Incorporated into Ni-based Cermets by Solution Precursor Plasma Spraying (SPPS) on Anode Stability. ECS Trans. 2011, 35, 1303-1313. [CrossRef]

46. Wang, Y.; Coyle, T.W. Solution Precursor Plasma Spray of Porous $\mathrm{La}_{0.8} \mathrm{Sr}_{0.2} \mathrm{MnO}_{3}$ Perovskite coatings for SOFC cathode application. J. Fuel Sci. Technol. 2011, 8, 021005. [CrossRef]

47. Prakash, B.S.; Kumar, S.S.; Aruna, S.T. Microstructure and performance of LSM/YSZ based solid oxide fuel cell cathodes fabricated from solution combustion co-synthesized powders and by solution precursor plasma spraying. Surf. Coat. Technol. 2017, 310, 25-32. [CrossRef]

48. Ma, X.; Dai, J.; Zhang, H.; Roth, J.; Xiao, T.D.; Reisner, D.E. Solid oxide fuel cell development by using novel plasma spray techniques. J. Fuel Cell Sci. Technol. 2005, 2, 190-196. [CrossRef]

(C) 2018 by the authors. Licensee MDPI, Basel, Switzerland. This article is an open access article distributed under the terms and conditions of the Creative Commons Attribution (CC BY) license (http:/ / creativecommons.org/licenses/by/4.0/). 